\title{
Melodie di pietra by Adriana Rossi
}

\author{
Alessandra Capanna ${ }^{1}$
}

\begin{abstract}
In Melodie di pietre, Adriana Rossi has produced an in-depth analysis of the cloister of San Cugat on the basis of musical notions and symbolism. This provides us with an occasion for some brief reflections on the historic relationships between music and architecture.
\end{abstract}

Keywords Music and architecture - Musical symbolism - San Cugat . Medieval architecture $\cdot$ Cloisters

\section{Melodie di pietre by Adriana Rossi}

This history of the relationship between music and architecture has ancient roots. They are founded in the myth of Amphion, a young demi-god, the son of Zeus, who received from Hermes the gift of a golden lyre. Thanks to the magic of its notes, he was able to move the stones to construct the walls of Thebes. The myth creates an indissoluble link between matter and sound.

The schematic simplicity of the mythological story highlights the ordering and creative power of music, and delineates the features of the supreme creator, who embodies several figures in one: in him we can recognise the demiurgic spirit of a Leonardo or a Michelangelo, and more in general a tension, out of historic time, typical of the unknown figures who almost unconsciously pursued the synthesis of all the arts in the construction of sacred buildings. Such were the unknown medieval master builders who worked so that architecture would reproduce the harmony of the cosmos here on earth, thanks to perfect and resonating proportions.

Alessandra Capanna

alessandra.capanna@uniroma1.it

1 Dipartimento di Architettura e Progetto, Sapienza Università di Roma, via Flaminia 359, 00196 Rome, Italy 
Such cosmology spread over the course of human history, leaving behind powerful testimonies in the great megalithic structures that are still today largely undeciphered, built by men who even before the cathedrals dipped into Pan's knowledge capable of communicating complex and transcendent concepts, made simple in virtue of image and the use of symbols that were meaningful and well understood. The divine and perfection coincided in the physical representation of sound.

For the ancients the uniform circular motion of the heavenly bodies was the origin of beauty, a beauty that became an intellectual as well as emotional experience, so much so that this immaterial existence of mathematical concepts that regulated the universe formed the bases for entire systems of philosophy.

At that point abstract ideas and concrete reality were interwoven and reciprocally dependent on each other, so that it was practically impossible to separate them. For a long time the symbolic significance manifested a natural testimony, founded on associations of ideas that we no longer possess, but which functioned as metaphors do today, since nothing exists in imagination which is not first manifest to the senses.

Studies of the harmony of the celestial spheres has shown that, above all during the late phase of the development of Platonic thought, together with the idea of sound as a primordial generating phenomenon, from which derived all of the other equalities - planets, seasons and so forth — there gradually came into play a system of analogies in which the series of sounds constitutes a form of expression specific to a structuring rhythmic order.

Fully expressive of this idea are the Catalonian cloisters, near Barcelona, Spain, of San Cugat, Gerona (English Girona) and Ripoll, built in the twelfth century. The columns that delimit the cloisters are placed in succession according to the images sculpted on their capitals, arranged according to a seemingly very simple composition constituting the decorated perimeter of a central void.

Instead, a historic and philological analysis has proven that the sequence of columns expresses both the symbolic logic that attributed to some animals and biblical motifs a precise musical note, and an astronomical logic that manifested the coincidence of spatial and temporal values in the dual identification of number as both an expression of universal laws and an expression of sound.

These are the themes examined by Adriana Rossi in her book Melodie di pietre (Fig. 1) published in the book series 'Archeoscienza' of Edizioni Scientifiche e Artistiche in Torre del Greco (Naples). An elegant and in-depth text, contained in over 400 pages, addresses each of the themes with precision and a wealth of iconographic and bibliographic apparatuses. The volume is written in Italian, with an English abstract provided at the end, and is accompanied by a thoughtful preface by historian of architecture Cesare de Seta, who discusses the value and cultural role of design, both as a representation of a universal cosmology and as a restitution of exact measurement and gnoseological category.

Prof. Rossi concentrates on the cloister of San Cugat, of which she reproduces an extremely accurate survey that becomes an instrument for understanding and verifying the interpretations and transcriptions that the German ethno-musicologist 
Fig. 1 The cover of Melodie di pietre

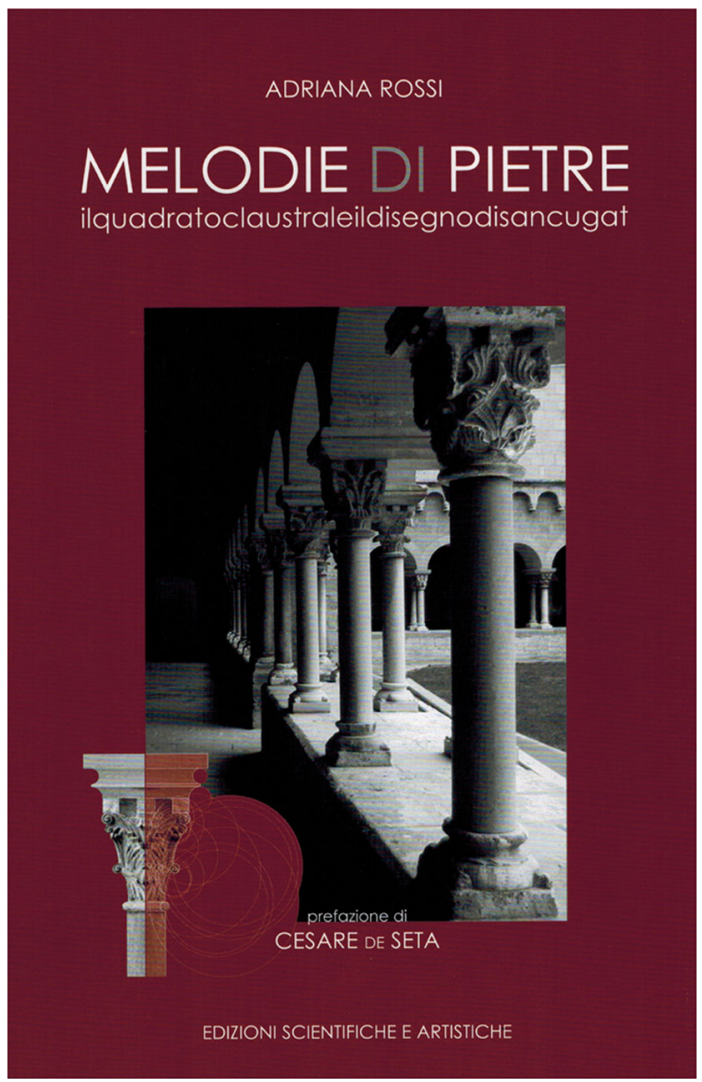

Marius Schneider had first published in German in 1955. ${ }^{1}$ In his book on 'singing stones' (1955), he reconstructed for the first time the musical sequence of the various animals sculpted on the 144 twinned capitals of the cloister of the Abbey of San Cugat and the 59 columns of the cathedral of Gerona.

What Adriana Rossi has published is, therefore, an important study that goes deeper into the historical-cultural aspect, going through the different levels of knowledge of the architectonic work with the classical means of drawing but also with the use of digital technologies to perform listening tests of sounds produced by the symbolic sequences. The system used to transfer them onto a modern musical staff - today composed of five lines marked by seven tones and five semi-tones-is illustrated in detail (although in truth this is already superseded by writing by means of the software used for electronic composing), while in earlier epochs music was written on a staff of four lines, with alphabetic symbols or neumatic notation.

Of particular interest is the third chapter, which describes four kinds of rhythm: musical, astral, narrative and informational, which leads to the hypothesis of an

\footnotetext{
1 Among other things, Marius Schneider is the author of a key text for understanding the symbolic significances inherent in musical compositions (Schneider 1970).
} 
algorithmic arrangement of the musical notes and of the score of the Gregorian chant dedicated to the patron saint.

The book is impossible to summarise in a short space, but merits a patient and sequential reading of the various passages that the author describes, as she was forced to make explicit historical intersections and parallelisms that are pluridisciplinary and transcultural.

Seeking to uncover the symbolic and musical values connected to animals in the most remote sacred texts of India, in the most ancient Hebrew traditions, in the iconic liturgical conventions of early Christianity, Prof. Rossi transforms her volume into a sieve that captures even the smallest detail of the links between the animal and the sounds and, more in general, the nature of the spirit.

If it were only seen in this light, the contribution of this book, for all that it is exhaustive in the carefulness of the research and evocative in the vastness of the topics examined, would be a mere deepening of the work of the German ethno-musicologist. The particular nature of the book, however, is in the depth of the investigations, which insist on the unravelling of the inaudible harmony and the melody that emerges from the silence. It is in the author's most heartfelt pages that we see the evocation of a mystical climate in which, of the sublime canticle of the many creatures, to human ears is conceded only a small part. Like ultrasonic frequencies, perceived by various animals but unheard by us, the symphony of the sounds that echo from the capitals of San Cugat do not penetrate into our body, but go directly to our soul! For Rossi, this is a melody that is inaudible and inexpressible, a great chorus that creation lifts aloft to its Creator, silent to our ears, but ecstasy to our souls.

The idea of giving physical shape to musical phenomena is typical of the medieval period, as shown by the representation of the tones or modes of Gregorian chants on the recovered capitals of the Abbey of Cluny, where the music of paradise was sung, and the human figures, dancers and musicians that serve as musical symbols were expressly accompanied by writings that indicated each of the tones that they represented.

The connection with sound that is typical of the Middle European cathedrals, even in the simplest expressive forms, has been lost in Western architecture, reduced to the satisfaction of technical and functional needs of the buildings used for theatrical performances, where problems of acoustics determine the shape of the halls and sometimes of the entire building.

But the great Gothic gargoyles with their mouths wide open "play music" by means of the rain passing within them, once again expressing, even in a small detail of a completely practical nature, the theme of universal consonance.

Rhythm and sound, which are, we might say with Lukács (1970: Ch. 4), primordial manifestations of the original substance of the universe, are imitazione del comando risonante che un tempo diede vita al mondo e insieme il gettare un ponte tra cielo e terra sulla base della sostanza musicale comune ai due mondi' (an imitation of the resonant command that once gave life to the world and at the same time the building of a bridge between heaven and earth on the basis of the musical substance that is common to both worlds). ${ }^{2}$

\footnotetext{
${ }^{2}$ From (Schneider 1970: 23). The text compares the compositional structure of the cloisters of San Cugat, Gerona and Ripoll from the musicological point of view.
} 
Knowledge of the great works of the past and a latent dissatisfaction in the face of many among those of our own day has sometimes made us dream of an architecture that would be like music, a direct language of passions, not subject to the necessities of a residence or a workplace. The risk is that of letting ourselves get carried away by an inclination like that of Baudelaire, that is, of seeking 'correspondences' that substantially depend on the readings that often go no further than the conjecture of how to understand the musical nature of architecture and the architectonic nature of music.

We conclude with a statement, taken from Schneider's book:

a 'modest melody' certainly cannot constitute the basis for an ordering of capitals of 'such sublime mysticism': this is a thesis of little value, especially if nothing more specific about this 'sublime mysticism' is said. Let us admit that the idea of 'stone that sings' does not appear clear to an observer who nonmusical and too modern (i.e., not equipped acoustically); this is not yet proof of the fact that age and a theology, which placed the Word at the beginning of creation and the song of praise at the heart of the act of worship, did not think differently in this regard (Schneider 1976: 34, our trans.).

The statement is a premise for the construction of a body of investigations that are scientifically supported by Adriana Rossi, who leads us back, by means of the knowledge of this ancient cloister, to a time that is by now lost. We echo the plea that Paul Valéry (1921) attributed to Socrates in his Eupalinos, or The Architect: je veux entendre le chant des colonnes, et me figurer dans le ciel pour le monument d'une mélodie. Cette imagination me conduit très facilement à mettre d'un côté, la Musique et l'Architecture; et de l'autre, les autres arts (I would hear the song of the columns and visualise in the pure sky the monument of a melody. This conceit very easily leads me to set on one side Music and Architecture; and over against them, the other arts) (Valéry 1956: 91).

Translated from the Italian by Kim Williams.

\section{References}

Lukács, György. 1970. Estetica. Torino: Einaudi.

Schneider, Marius. 1955. Singende Steine. Rhythmus-Studien an 3 katalanischen Kreuzgängen romanischen Stils. Kassel/Basel: Bärenreiter (revised 2nd edition, It. trans. Pietre che cantano: Studi sul Ritmo di tre chiostri catalani di stile romanico, Milan, SE editori, 1976).

Schneider, Marius. 1970. Il significato della musica. Milan: Rusconi.

Valéry, Paul. 1956. Dialogues. Jackson Mathews, trans. Bollingen Series XLV 4. Princeton: Princeton University Press.

Valéry, Paul. 1921. Eupalinos ou L'architecte, dialogue des morts, Extr. de la Nouvelle Revue Française, 12 mars.

Alessandra Capanna Architect, PhD, Professor in Architectural Composition in Bachelor's and Master's Degree courses, and Phd seminars. Since 1999 to 2001 she joined LaMA Multimedia Architecture Lab a structure of the Department of Architecture producing video and multimedia and, as component of QART, Laboratory for the Study of Contemporary Rome, she conducted the research "School reform and its significance in school regulation and tipology ...", published in 2013 in the book Edifici per la scuola. 
She has talks at international Conferences speaking about the relationships amongst Mathematics, Music and Architecture. Author of numerous projects for private houses, in 1992 she set up the exhibition of 5th Biennale d'arte sacra at Isola del Gran Sasso (TE). From 2009 to 2013 corresponding editor of Nexus Network Journal. From 2011 component of the scientific board in cultural activities with Conservatorio di S. Cecilia in Roma. From 2014 she is developing the Research program "Ambienti, stanze e altri spazi sonori. Sperimentazioni progettuali di contesti multisensoriali”. Other info at: https://www.researchgate. net/profile/Alessandra_Capanna. 